Provided for non-commercial research and education use. Not for reproduction, distribution or commercial use.

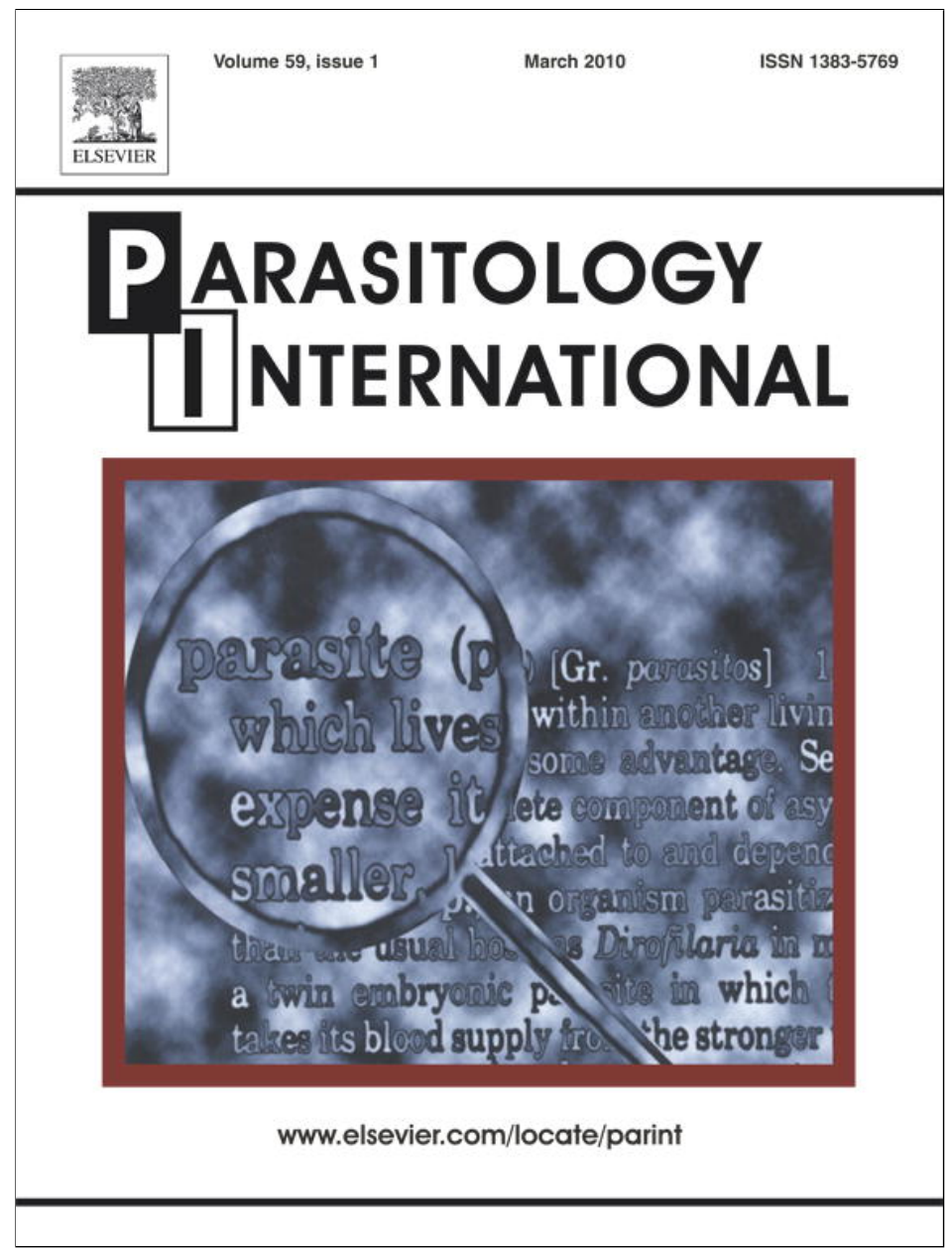

This article appeared in a journal published by Elsevier. The attached copy is furnished to the author for internal non-commercial research and education use, including for instruction at the authors institution and sharing with colleagues.

Other uses, including reproduction and distribution, or selling or licensing copies, or posting to personal, institutional or third party websites are prohibited.

In most cases authors are permitted to post their version of the article (e.g. in Word or Tex form) to their personal website or institutional repository. Authors requiring further information regarding Elsevier's archiving and manuscript policies are encouraged to visit:

http://www.elsevier.com/copyright 


\title{
Development of a PCR-RFLP marker to genetically distinguish Prosorhynchus crucibulum and Prosorhynchus aculeatus
}

\author{
Claire Juliana Francisco a,b,*, André Almeida ${ }^{\mathrm{c}, \mathrm{d}}$, António Manuel Castro ${ }^{\mathrm{c}}$, Maria João Santos a,b \\ a Universidade do Porto, Faculdade de Ciências, Departamento de Zoologia/Antropologia Rua do Campo Alegre, 4169-007 Porto, Portugal \\ b CIMAR Laboratório Associado /CIIMAR, Centro Interdisciplinar de Investigação Marinha e Ambiental, Rua dos Bragas, 289, 4050-123 Porto, Portugal \\ c Instituto Nacional de Saúde Dr. Ricardo Jorge, Departamento de Doenças Infecciosas, Rua Alexandre Herculano, 321, 4000-055 Porto, Portugal \\ d Instituto de Ciências Biomédicas de Abel Salazar, Largo Prof. Abel Salazar, 2, 4099-003 Porto, Portugal
}

\section{A R T I C L E I N F O}

\section{Article history:}

Received 19 February 2009

Received in revised form 24 September 2009

Accepted 29 September 2009

Available online 8 October 2009

\section{Keywords:}

Prosorhynchus crucibulum

Prosorhynchus aculeatus

$18 \mathrm{~S}$ rDNA region

Molecular identification

\begin{abstract}
A B S T R A C T
The cercariae stages of Prosorhynchus crucibulum and Prosorhynchus aculeatus are morphologically indistinguishable. However, the differentiation of these two species is crucial to understand the transmission dynamics between these primary hosts (mussels) and the secondary hosts (fish). In this way, the objective of this study is to develop an accurate molecular identification tool to differentiate the cercariae stage of $P$. crucibulum and P. aculeatus. We targeted the $18 \mathrm{~S}$ nuclear ribosomal DNA region by PCR amplification and sequenced this amplicon. By generating these sequences, we developed a RFLP tool with the use of the enzymes HincII and FokI that produced different restriction profiles between P. crucibulum and P. aculeatus. Each enzyme generated different-sized fragments specific to the species examined and no cross-reaction between the species was detected in their restriction pattern. By sequencing, no intraspecific-polymorphism was detected since there is $100 \%$ homology among P. aculeatus or P. crucibulum. These results indicate that PCR-linked restriction analysis of the $18 \mathrm{~S}$ rDNA region provided us with rapid and reliable molecular tools for distinction of the cercariae of these species. The sequences generated were deposited in GenBank accession numbers for P. crucibulum cercariae (FJ463407, FJ463408 and FJ463409) and adult worm (FJ429096, FJ429097), and for P. aculeatus adult (FJ429094 and FJ429095).
\end{abstract}

(c) 2009 Elsevier Ireland Ltd. All rights reserved.

\section{Introduction}

Prosorhynchus crucibulum (Rudolphi, 1819; Odhner, 1905) and P. aculeatus (Odhner, 1905) are parasites of the Bucephalidae family, with a complex life cycle, infecting successive hosts in the marine environment: the adult stage development occurs inside the digestive tract of Conger conger, where they reproduce asexually and produce eggs that will be released with the host faeces; inside the egg the development of the miracidium takes place, the first larval phase in the worm life cycle; this miracidium infects the mussels, the first intermediate host, where it develops into a sporocist, which reproduces asexually and generates innumerable cercariae. It was reported that the larval form of Prosorhynchus spp. infects the fishes (Sole sole, Scophitalmus maximus, Limanda limanda, Onus mustelus, Pomatoshistus minutus, Pomatomus saltatrix, Liparis liparis, Boops boops and Pleuronectes flesus) and encysts into a metacercariae [1-8]; those infected hosts will be eaten by conger eels developing the adult form and thus closing the life cycle.

In southern Europe, Mytilus spp. is a highly appreciated mollusk and therefore an important commercial species; it is the first

* Corresponding author. Universidade do Porto, Faculdade de Ciências, Departamento de Zoologia/Antropologia Rua do Campo Alegre, 4169-007 Porto, Portugal.

E-mail address: clairejulianaf@yahoo.com.br (C.J. Francisco). intermediate host of the bucephalid digenean Prosorhynchus sp. $[3,9,10]$. The bucephalid of the genus Prosorhynchus had been described as causing serious problems, like castration and weakening of the adductor muscle [11-17]. Furthermore, molecular data from these worms are limited, since in the GenBank there is one sequence deposited referring to the genus of Prosorhynchus sp. and not specifying the species.

Taking into account the fact that $P$. crucibulum and $P$. aculeatus are morphologically undistinguishable at cercariae stage, but not in adult stage, the molecular analysis could be a useful tool to identify the species of these parasites at early stages. In this way, the main aim of this study is to develop molecular markers, that would allow us to rapidly distinguish the cercariae of the $P$. crucibulum and $P$. aculeatus using PCR-RFLP analysis of the $18 \mathrm{~S}$ nuclear ribosomal DNA partial region, and thus, collaborate in the development of tools for controlling this parasite.

\section{Materials and methods}

\subsection{Species identification and sequences examined}

The adult worms of $P$. crucibulum and P. aculeatus were isolated from the digestive tract of Conger conger fish, and the main differences 
observed were the size and shape of the rhynchus at the anterior end, which in P. crucibulum is larger and triangular and in P. aculeatus is small and oval $[3,18]$. The cercariae were collected in the mantle from Mytilus galloprovincialis. For identification of the genus of the cercariae, their morphology was compared with that of $P$. squamatus and $P$. crucibulum $[3,19]$. In order to identify the species, molecular analysis was performed. For that and since there are no molecular data for these two species deposited in the GenBank, we obtained nucleotide sequences from several genera including Prosorhynchus $s p$., as suggested in the literature [20], and after alignment of these homologous sequences, primers targeting a fragment of the $18 \mathrm{~S}$ rDNA were designed.

\subsection{DNA preparation, amplification and sequencing}

Adult worms of P. crucibulum ( $n=1,5,10,15$, and 22$)$ and Prosorhynchus aculeatus ( $n=1,5,8,13$ and 22) were collected from the digestive tract of 14 conger eels (Conger conger). The worms were washed in saline solution and stored in 70\% ethanol. A commercial kit (QIAGEN) was used to extract DNA from worms according to the protocol of the manufacturer. Three samples of cercariae from Mytilus galloprovincialis $(n=3)$, its intermediate host, were collected from Aveiro estuary $\left(40^{\circ} 38.620^{\prime} \mathrm{N} 8^{\circ} 44.802^{\prime} \mathrm{W}\right)$, for genus identification. In order to obtain molecular data that enable us to distinguish the two worm species by sequencing or by the use of restriction sites, a partial region of the $18 \mathrm{~S}$ rDNA was amplified by PCR using the primers obtained by us: SSU_Fwd (5'TCTGGGTCGCATC3') and SSU_Rev (5' CCATTACTTCGGATC $3^{\prime}$ ). Sensitivity of the PCR method was accessed by using different numbers of the adult worms.

PCR was performed using the described primers in a total volume of $50 \mu$ l. Each reaction contained 1 standard unit Taq polymerase (Thermo Scientific), $5 \mu \mathrm{l}$ PCR buffer $10 \times, 4 \mathrm{mM} \mathrm{MgCl}_{2}, 0.2 \mathrm{mM} \mu \mathrm{dNTP}$ (Roche), $200 \mathrm{nM}$ of each primer, 5 and $10 \mu$ template DNA of $P$. crucibulum and $P$. aculeatus, respectively, made up to $50 \mu \mathrm{l}$ with water. This mix was placed in a ThermoCycler Primus 25/96 Hain Lifescience with the following conditions: initial hot start of $94{ }^{\circ} \mathrm{C}$ during $4 \mathrm{~min}$ followed by 40 cycles of $95^{\circ} \mathrm{C}$ for $30 \mathrm{~s}, 40^{\circ} \mathrm{C}$ for $30 \mathrm{~s}$ and $72^{\circ} \mathrm{C}$ for $30 \mathrm{~s}$. Final extension of the product was at $72^{\circ} \mathrm{C}$ for $5 \mathrm{~min}$.

After amplification, the PCR products were checked by electrophoresis in a $1 \%$ agarose gel (BioRad) and fragment sizes were estimated using a $\lambda$ DNA-HindIII digest ladder (New England BioLabs). For PCR product purification, a low melting $1 \%$ agarose gel was made (Promega) and a commercial kit (GFX PCR DNA and Gel band purification kit, GE Healthcare) was used according to the manufacturer's instructions. DNA fragments were sequenced in both strands in an external laboratory (EUROFINS MWG OPERON, Germany). The sequences obtained were compared with the sequences in the Genbank by using the Blastn tool (www.ncbi.nlm. nih.gov). These sequences were aligned with reference to the $18 \mathrm{~S}$ rDNA region from Prosorhynchus sp. (AJ224458) within PROSEQ ${ }^{\circledR}$ version 2.91 (ProSeq, Dimitri Filatov). Sequence data from the two species were compared and restriction analysis simulated in the software MB ${ }^{\circledR}$ DNA Analysis 6.82 (Molbiosoft, Oleg Simakov).

\subsection{PCR-RFLP analysis}

The PCR-amplified products were then subjected to digestion with two restriction enzymes within the 18S rDNA partial region: FokI and HincII. Digestion was performed in a total volume of $20 \mu \mathrm{l}$ containing $17.3 \mu \mathrm{l}$ of PCR product, 5 units of restriction enzyme ( $10 \mathrm{units} / \mu \mathrm{l})$ (Promega), $2 \mu \mathrm{l}$ of $10 \times$ reaction buffer, and $0.2 \mu \mathrm{l}$ of BSA $(10 \mu \mathrm{g} / \mu \mathrm{l})$ at $37^{\circ} \mathrm{C}$ for $1 \mathrm{~h} 30 \mathrm{~min}$. The resulting restriction fragments were separated by electrophoresis in $2 \%$ agarose gel. Restriction profiles of digested PCR products were checked, using UV illumination in Gel Documentation System (BioRad), by comparison with molecular markers of 50 bp (50 bp DNA ladder, New England BioLabs).

\section{Results}

Concerning the sensitivity, the PCR was positive when applied to the DNA extracted from 1, 5, 10, 15 and 22 adult worm of P. crucibulum and 1, 5, 8, 13 and 22 adult worms of P. aculeatus (Fig. 1).

The PCR products of the adult worms sequenced in both directions showed high similarity to Prosorhynchus sp. but also presented some differences. This molecular analysis of the sequences from the $18 \mathrm{~S}$ rDNA partial region (Fig. 2) of adult worms of P. crucibulum and $P$. aculeatus revealed fixed nucleotide differences that allow us to distinguish these two species. These sequences were deposited in the GenBank under the accession nos. FJ429096 and FJ429097 for $P$. crucibulum and FJ429094 and FJ429095 for $P$. aculeatus. The sequences showed no intragenic variation once no differences were found inside the sequences of $P$. crucibulum or $P$. aculeatus. The identification of cercariae was made by PCR and sequencing taking into account the differences in DNA sequence previously observed in adult worms. These data were deposited in the GenBank under the accession nos. FJ463407, FJ463408 and FJ463409. We observe that all cercariae were identified as P. crucibulum with $100 \%$ homology, and no differences were observed between the sequences of cercariae and adult worms of $P$. crucibulum (Figs. 2 and 3 ).

The PCR-RFLP of the 18S rDNA partial region using restriction enzymes HincIl and FokI generated different-sized fragments specific to the species examined (the adult worms) confirmed by sequencing. These results were compared with the digestion of the 18S rDNA partial region of cercariae. The Hincll enzyme cuts twice the 18S rDNA $P$. crucibulum sequence (at 118 and $151 \mathrm{bp)}$ ) creating five possible bands in the agarose gel $(33,118,151,166$, and $199 \mathrm{bp})$, although only 118 bp, 166 bp and 199 bp bands are observed. In P. aculeatus $18 \mathrm{~S}$ rDNA sequence, the same enzyme cuts only in one position (151 bp) creating two bands of 151 and $166 \mathrm{bp}$ in the agarose gel (Fig. 4). For the same PCR, the FokI enzyme cuts the 18S rDNA sequence in only one site, at $176 \mathrm{bp}$, creating two bands (176 and 141) and did not digest the PCR fragment of $P$. aculeatus (Fig. 5). The use of HincII and FokI enzymes in the 18S rDNA region produced the same restriction pattern in the cercariae as in the adult.

\section{Discussion}

The knowledge of the genotype from the two species is relevant to our understanding of these species life cycle, as well as the development of reliable molecular tools for the distinction between cercariae of the $P$. crucibulum and $P$. aculeatus. In 1973, the morphology and life cycle of $P$. crucibulum was reported [3] and the life cycle of the $P$. squamatus was also confirmed [19]. Matthews [3] verified that both cercariae developed in branching sporocysts in Mytilus edulis and the metacercariae encysted in eight fishes that served as second intermediate hosts. However, the cercaria stage of $P$. crucibulum and P. squamatus is easily distinguished, by showing

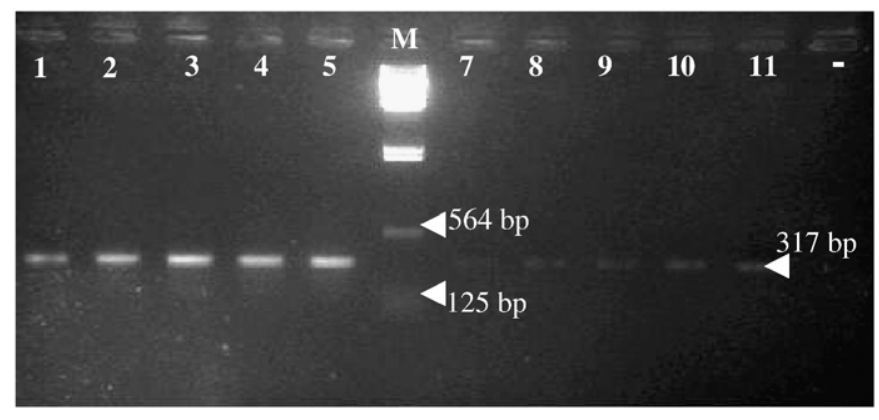

Fig. 1. Sensitivity of PCR applied to the extracted DNA. Lanes 1-5 Prosorhynchus aculeatus; Lane 6 (M): DNA/HindIII-23130pb marker; Lanes 7-11 P. crucibulum; Lane $12(-)$ : negative. 


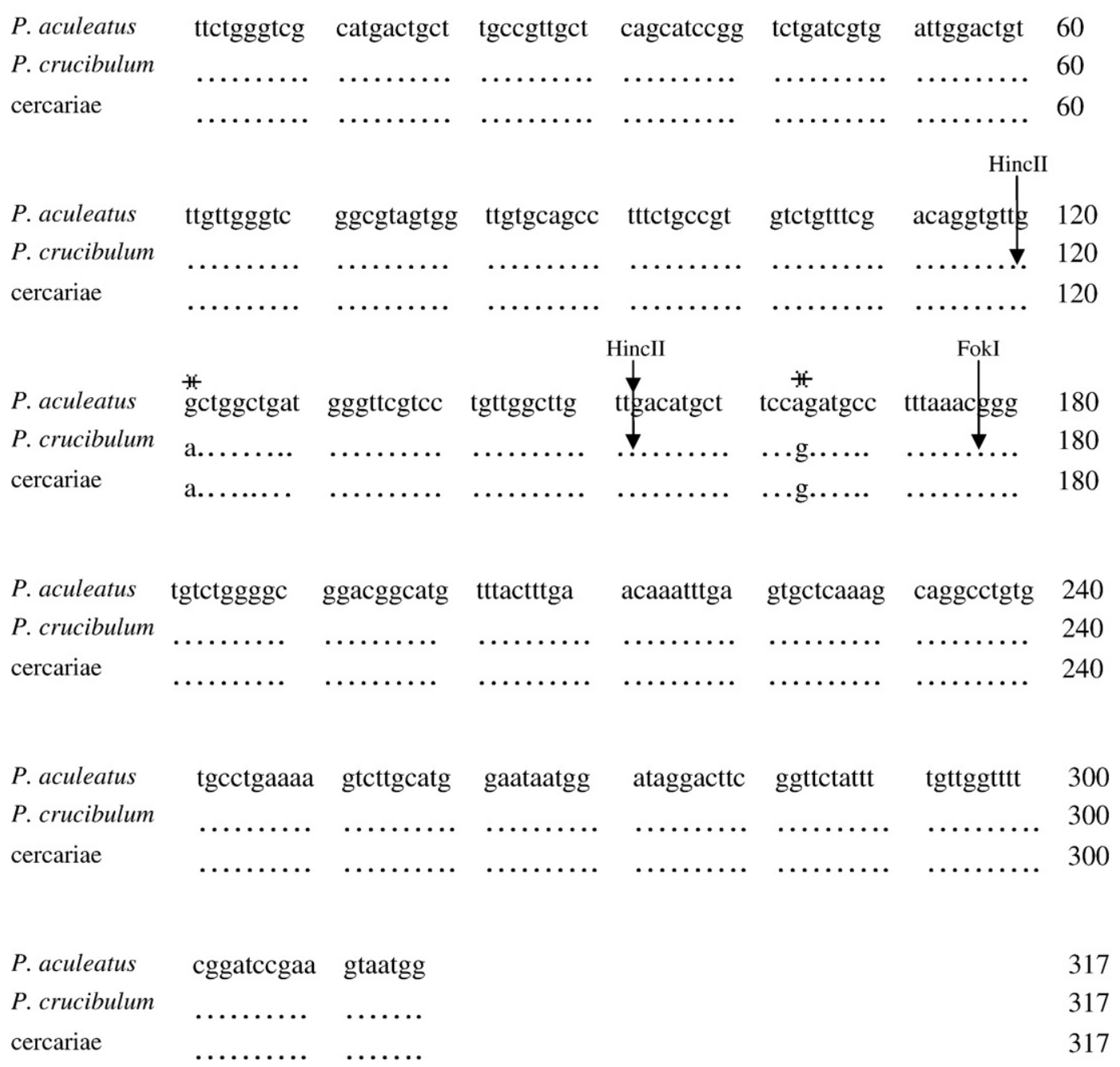

Fig. 2. Sequence alignment of $18 \mathrm{~S}$ rDNA partial region from Prosorhynchus aculeatus (adult worm), and P. crucibulum (cercariae and adult). (asterisks): polymorphic sites; (arrows): cut sites by the HinclI or FokI restriction enzymes.

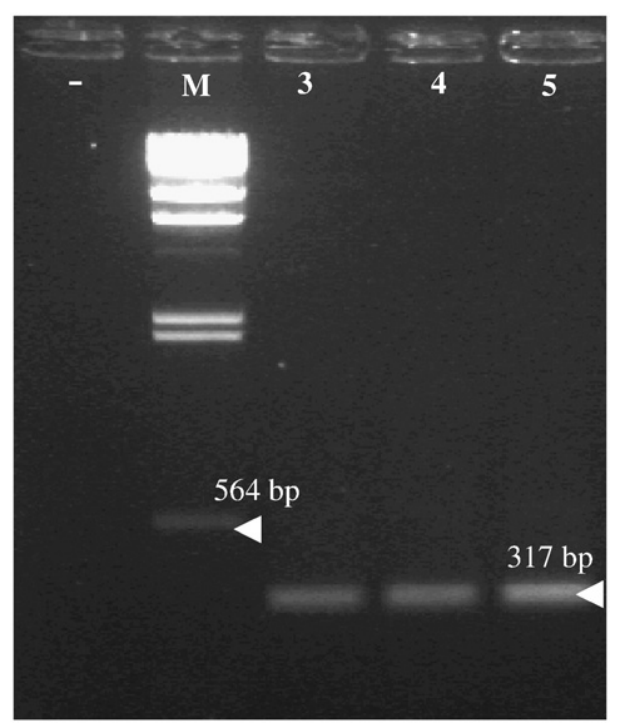

Fig. 3. Electroforesis of the PCR over the DNA of the cercariae isolated from Mytilus galloprovincialis. Lane $1(-)$ : negative; Lane $2(\mathrm{M})$ : lambda DNA/HindIII-23130pb marker; Lanes 3-5, PCR products of DNA of cercariae.

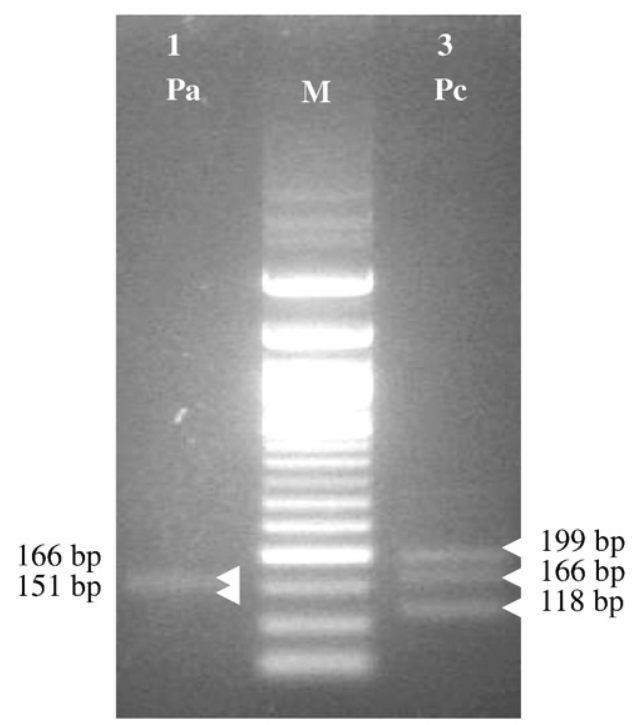

Fig. 4. HinclI-digested PCR products display different profiles corresponding to the expectation of restriction maps. Lane 1 (Pa): Prosorhynchus aculeatus; Lane $2(\mathrm{M})$ : Marker 50 bp; Lane 3 (Pc): P. crucibulum. 


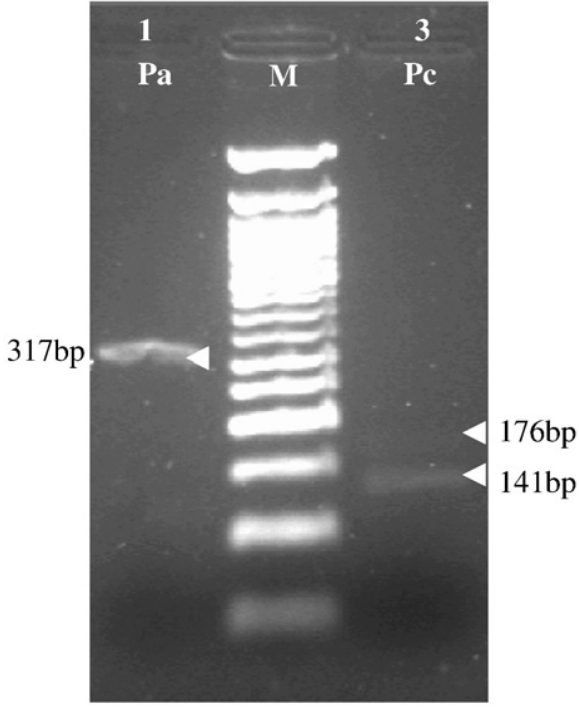

Fig. 5. FokI-digested PCR products, displaying different profiles corresponding to the expectation of restriction maps. Lane 1 (Pa): Undigested PCR products of Prosorhynchus aculeatus; Lane 2 (M): Marker 50 bp; Lane 3 (Pc): P. crucibulum.

differences in the morphology of the base of the tail. The anatomy of the adult worm Skrjabiniella aculeatus (Odhner), later renamed $P$. aculeatus [18] is well known, however, the life cycle of this parasite is yet little understood. It is known that a bivalve is the first intermediate host in the marine environment, and the definitive host of $P$. crucibulum and P. aculeatus parasites is Conger conger [8,21,22].

Few studies are available about the polymorphism between the species $P$. crucibulum and $P$. aculeatus. This information is essential for the development and refinement of systems for pathogen identification using molecular tools. In 1999, the phylogenetic relationship within the $18 \mathrm{~S}$ rDNA partial region between 13 species of Fellodistomidae from four subfamilies and eight species from seven other digenean families was reported. In this research, the $18 \mathrm{~S}$ rDNA partial region of Prosorhynchus sp. from family Bucephalidea was obtained, and it was possible to compare our results within the Genbank database with the results of Prosorhycnhus sp. [20], from the same V4 partial region. The cercariae from $P$. crucibulum and $P$. aculeatus are morphologically undistinguishable owing to the life cycle of this parasite being as yet poorly understood. The differentiation of these two species is crucial to understand the transmission dynamics between the primary and secondary host, the fish. In this way, the development of a molecular tool able to differentiate the cercariae stage of both species is crucial. We targeted the $18 \mathrm{~S}$ nuclear ribosomal DNA partial region and generated data concerning the DNA sequence of the species $P$. aculeatus and $P$. crucibulum previously characterized according to morphological aspects. We observed fixed differences in the DNA sequence between the two species of parasites, $P$. aculeatus and P. crucibulum: two polymorphic sites within the $18 \mathrm{~S}$ partial region (121 pb and $164 \mathrm{pb}$ of the amplified product) which enable us to differentiate the two species. A $100 \%$ homology was detected between all the $P$. crucibulum sequences or $P$. aculeatus sequences. Additionally, we verified that only one adult worm DNA sample can yield enough DNA for detection by PCR method. The PCR-RFLP is a rapid, easy and cheap technique used in species identification. Based on these DNA differences between the two species, restriction enzymes HincIl and FokI enabled us to easily distinguish the cercariae of species P. crucibulum and P. aculeatus.

\section{Acknowledgements}

The authors wish to thank the National Institute of Health, Department of Infectious Diseases, without which the realization of this work would not have been possible. We are also indebted to CAPES for the PhD grant no. 37787-053 to Claire Juliana Francisco.

\section{References}

[1] Manter HW. Some digenetic trematodes of marine fishes of Beaufort, North Carolina. Parasitology 1931;23:396-411.

[2] Rebecq J, Leray C. Metacercaires de Prosorhynchus crucibulum (Rudolphi 1819) (Trematoda, Bucephalidae) chez deux Gobiesocidae (Téléostéens). Vie Milieu 1961;12:378-80.

[3] Matthews RA. The life-cycle of Prosorhynchus crucibulum (Rudolphi, 1819) Odner, 1905, and a comparison of its cercaria with that of Prosorhynchus squamatus Odhner, 1905. Parasitology 1973;66:133-64.

[4] Munson DA. Parasites of the tide pool fish Liparis atlanticus. J Wildl Dis 1974;10:256-62.

[5] Papoutsoglou SE, Papaparaskeva-Papoutsoglou EG. Metazoan parasites of Solea Solea (L.) from Porto-Lago, North Aegean Sea, Greece. Mem Biol Mar Oceanogr 1977;7:21-33.

[6] Anato CB, Ktari MH, Dossou CH. La parasitofaune métazoaire de Boops boops (Linné, 1758), poisson téléostéen Sparidae des côtes tunisiennes. Oebalia 1991;17:259-66.

[7] Alvarez F, Iglesias R, Pamara AI, Leiro J, Sanmartin M. Abdominal parasites of commercially important flatfishes (Teleostei: Scophthalmidae, Pleuronectidae, Soleidae) in northwest Spain (ICES IXa). Aquaculture 2002;213:31-53.

[8] Durieux EDH, Marques JF, Sasal P, Bégout M-L, Cabral HN. Comparison of Solea solea macroparasites between two nursery-continental shelf systems in the Bay of Biscay and the Portuguese coast. J Fish Biol 2007;70(6):1921-30.

[9] Cousteau C, Combes C, Maillard C, Renaud F, Delay B. Prosorhynchus squamatus (Trematoda) Parasitosis in the Mytilus edulis - Mytilus galloprovincialis complex: specificity and host-parasite relationships. Pathol Mar Sci 1990:291-8.

[10] Teia dos Santos AM, Coimbra J. Growth and production of raft-cultured Mytilus edulis L., in Ria de Aveiro: gonad symbiotic infestation. Aquaculture 1995;132:195-211.

[11] Shelley CC, Glazebrook JS, Turak E, Winsor L, Denton GRW. Trematode (Digenea: Bucephalidae) infection in the burrowing clam Tridacna crocea from the Great Barrier Reef. Dis Aquat Org 1988;4:143-7.

[12] Costeau C, Renaud F, Delay B, Robbins I, Mathieus M. Mechanisms involved in parasitic castration: in vitro effects of the trematode Prosorhynchus squamatus on the gametogenesis and the nutrient storage metabolism of the marine bivalve mollusc Mytilus edulis. Exp Parasitol 1991;73:36-43.

[13] Lasiak T. Bucephalid trematodes infections in mytilid bivalves from the rocky interdital of southern Chile. J Molluscan Stud 1992;58:29-36.

[14] Cousteau C, Robbins I, Delay B, Renaud F, Mathieus M. The parasitic castration of the mussel Mytilus edulis by the trematode parasite Prosorhynchus squamatus: specificity and partial characterization of endogenous and parasite-induced antimitotic activities. Comp Biochem Physiol 1993;104A(2):229-33.

[15] Calvo-Ugarteburu G, Mcquaid CD. Parasitism and invasive species: effects of digenetic trematodes on mussels. Mar Ecol Prog Ser 1998;169:149-63.

[16] Silva PM, Magalhães ARM, Barraco MA. Effects of Bucephalus sp. (Trematoda: Bucephalidae) on Perna perna mussels from a culture station in Ratones Grande Island, Brazil. J Invertebr Pathol 2002;79:154-62.

[17] Cochôa AR, Magalhães ARM. Perdas de sementes de mexilhões Perna perna (L., 1758), cultivados na baía norte - ilha de Santa Catarina/SC. B. Inst. Pesca 2008; 34(1): 1 - 10

[18] Jones O. D. The anatomy of three digenetic trematodes, Skrjabiniella aculeatus (Odhner), Lecithochirium rufoviride (Rud.) and Sterrhurus fusiformis (Lühe) from Conger conger (Linn). Parasitology 1943;35(1-3):40-57.

[19] Chubrik GK. On the life cycle of the fish trematode, Prosorhynchus squamatus Odhner, 1905. Dokl Arad Nauk 1952;83:327-9.

[20] Hall KA, Cribb HT, Barker SC. V4 region of small subunit rDNA indicates polyphyly of the Fellodistomidae (Digenea) which is supported by morphology and life-cycle data. Syst Parasitol 1999;43:81-92.

[21] Cribb TH, Bray RA, Littlewood DTJ. The nature and evolution of the association among digeneans, molluscs and fishes. Int J Parasitol 2001;31:997-1011.

[22] Laffargue P, Baudoin G, Sasal P, Arnaud C, Bégout Anras M-L, Lagardère F. Parasitic infection of sole Solea solea by Prosorhynchus spp. metacercariae (Digenea, Bucephalidae) in Atlantic nurseries under mussel cultivation influence. Dis Aquat Org 2004;58:179-84 